Scientific Visualization, 2020, volume 12, number 5, pages 102 - 111, DOI: 10.26583/sv.12.5.09

\title{
Water flow speed determining using visualization methods
}

\author{
D.A. Antonenkov ${ }^{1}$ \\ Marine Hydrophysical Institute of RAS, Sevastopol, Russia \\ ${ }^{1}$ ORCID: 0000-0003-2601-7751, dmitry science@mail.ru
}

\begin{abstract}
$\underline{\text { Abstract }}$
Despite the variety of means for measuring the flow velocity, it remains relevant to develop new methods and modify the existing ones that will make it possible to obtain more information about the dynamics of the water flow. Currently, flows studies using visualization methods are gaining more and more popularity. The article discusses the developed by the author of the water velocity meter based on the PIV method, capable of working in natural conditions.

The use of natural suspended matter particles as tracers can significantly accelerate the experiments performance and reduce the cost of there implementation, which is important while working in the field. A description of the developed methodology and technical means for measuring the flow velocity is given. The results obtained during field tests are presented.

Owing to the modern visualization methods use, the created meter has a number of advantages in comparison with other devices for flow studies. In particular, it makes it possible to obtain instantaneous and averaged fields of the flow velocity distribution in a wide spatial and temporal range.
\end{abstract}

Keywords: flow velocity, water flow dynamics, video processing, PIV method, image anemometry, visualization methods.

Measuring the flow velocity is an important task in the field of environmental monitoring of water resources. Such data are necessary for the design and construction of hydraulic structures, for studying the dynamics of water flow, mechanisms of erosion and sediment movement, analysis of the ecological situation.

There are numerous methods and technical means for studying the water flow structure based on various physical principles, for example, acoustic Doppler profilometers ADCP, designed to study the spatial and vertical currents' structure [1], which can be applied both in a stationary position and in the tow mode $[2,3]$, devices using ultrasonic measurement technologies [4, 5], meters based on electromagnetic induction [6] and others that are analyzed in detail in this article [7]. The most common instruments for rivers are those whose operation is based on the registration of the number of turns of the blade rotor - hydrometric turntables [8]. They make it possible to measure the speed and direction of the current at different horizons. It is possible to distinguish among the express methods a method based on registering the speed of a floating body using various floats [9], having the simplest technical implementation. However, despite the variety of means for measuring the flow velocity, the development of new methods and modification of the existing ones remains relevant, which will allow avoiding some restrictions in their application, as well as to obtain more information about the water flow dynamics.

Currently, it is becoming more and more relevant to study flows using scientific visualization methods, one of which is the PIV method (Particle Image Velocimetry). This method is widely used in many areas, such as the automotive and aircraft industry, power engineering, in various scientific problems, for example, when modeling the processes of gas flows on the surface of solids [10], to measure the velocity in a selected flow section in hydro- and aerodynamic experiments. [11, 12, 13], to study the dynamics of velocity vector fields and flow vorticity using the method of the smoke image velocimetry (SIV) [14, 15, 16]. However, due 
to the complex technical implementation, in most cases, its use is limited to laboratory conditions.

The main goal of the work is to show the capabilities of the measuring instruments developed by the author based on the PIV method for studying the water flow in natural conditions.

Measurement of the flow rate using the PIV method is based on the analysis of the movement of particles located in the cross- section plane over a fixed time interval.

Particle images are illuminated using a pulsed illumination system and recorded on a digital camera. Subsequent image processing makes it possible to calculate the displacements of particles during the time between the light source flashes and to construct a twodimensional vector velocity field [17].

Cross-correlation of two consecutive images divided into fragments is used to determine the particle velocity. The cross-correlation function (1) is calculated for each fragment, and its maximum is sought.

$$
C(m, n)=\sum_{i} \sum_{j} I_{1}(i, j) \cdot I_{2}(i+m, j+n)
$$

where $C(m, n)$ - cross-correlation value for a pixel $(m, n)$;

$I_{1}(i, j)$ - pixel intensity $(i, j)$ of the first image fragment;

$I_{2}{ }^{\prime}(i+m, j+n)-$ pixel intensity $(i+m, j+n)$ of the second image fragment;

The standard fast Fourier transform algorithm is used to calculate the correlation function. For the two images fragments that are identical in coordinates, taken at a certain point at time $\Delta t$, their frequency representations are found using the fast Fourier transform. Next, a complex multiplication of the transformation results is performed, after which the inverse Fourier transform is performed. Then the maximum of the cross-correlation function is found [18]. For a more accurate determination of the maximum coordinates, the standard Gaussian interpolation procedure for the main peak is used [19].

The direction is determined by the coordinates of the maximum relative to the fragment center and the value of the displacement of the pixels $\mathrm{D}$, and then, knowing the time delay between frames $\Delta t$, the speed of particles movement is calculated [20]:

$$
V=S \frac{D}{\Delta t}
$$

where $\mathrm{S}$ is the scale factor for recalculating the speed in $\mathrm{m} / \mathrm{sec}$.

Technically, the classical scheme of the PIV method is implemented using high-power pulsed lasers (1-10 MW) and synchronous video shooting of specially used PIV cameras [21]. However, the implementation of such schemes in natural conditions is difficult, and therefore the PIV method is mainly used in laboratory conditions.

A meter was specially developed to study the dynamics of water flow in natural conditions, consisting of a backlight device, a digital video camera, attachment / positioning elements and data processing software. The scheme and the photo are shown in Figure 1. 


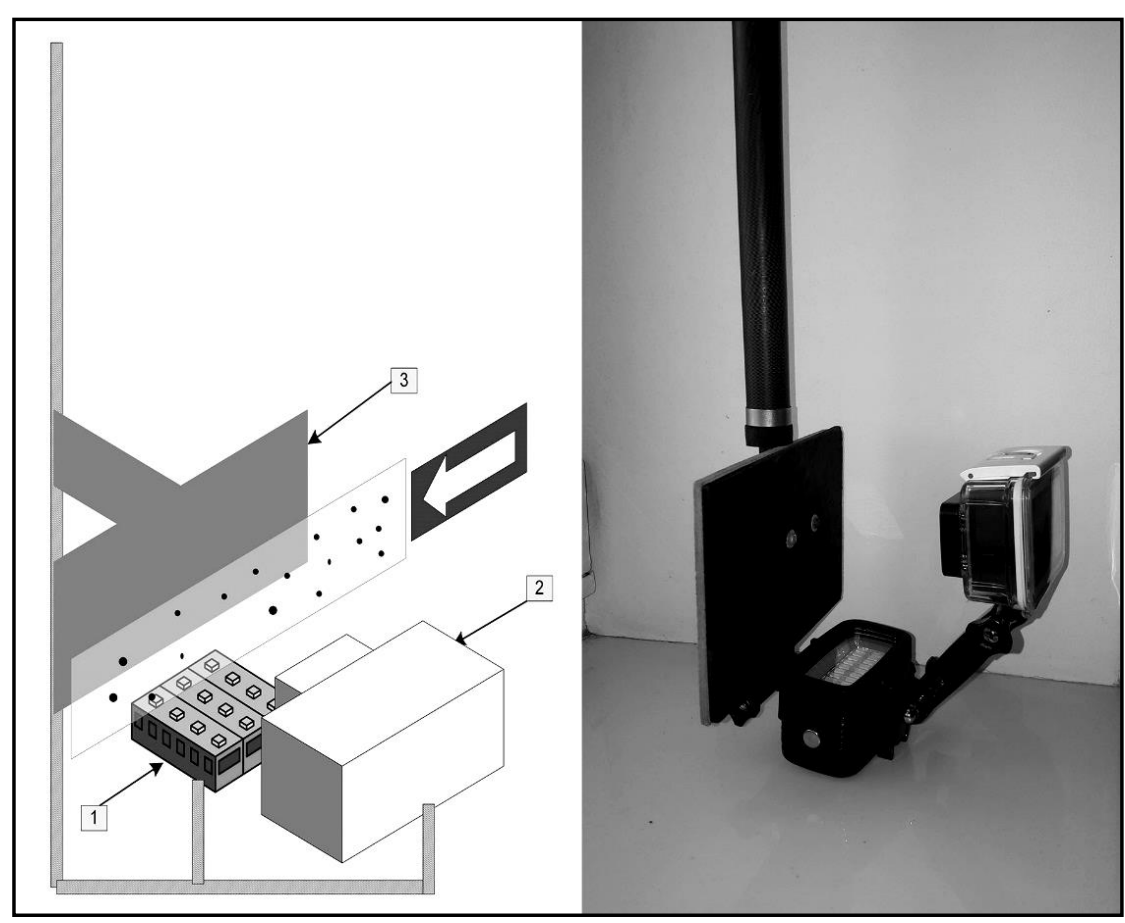

Figure 1 - Scheme and photo of the flow velocity meter.

A sealed light source - 1 was used as backlight, with 20 SMD 5730 LEDs with a total power of 20W, providing a luminous flux of $2200 \mathrm{LM}$. The movement of particles in the flow was recorded using a digital camera $\mathrm{YI}_{4} \mathrm{~K}+$, placed in a waterproof box - 2. The main characteristics are presented in Table 1 [22].

Table 1 - Main technical characteristics of a digital camera.

\begin{tabular}{|l|l|}
\hline Chipset: & Ambarella H2 SOC \\
\hline CPU: & Cortex-A53 ARM \\
\hline Working temperature: & $\mathrm{o}-45^{\circ} \mathrm{C}$ \\
\hline Battery life: & 120 min \\
\hline Matrix type: & CMOS \\
\hline Sensor: & Sony IMX377 \\
\hline Number of matrix pixels: & 12 megapixels \\
\hline Physical size of the matrix: & $1 / 2,3$ \\
\hline 4K video: & 60 frames/sec \\
\hline 108op video: & 120 frames/sec \\
\hline 720p video: & 240 frames/sec \\
\hline Universal connector: & USB Type-C \\
\hline Memory card support: & MicroSD, MicroSDHC \\
\hline Camera mount: & $1 / 4$ screw \\
\hline Battery Type: & removable, 1400 mA/h \\
\hline
\end{tabular}

The use of this camera is due to its compact size, high resolution and maximum frame rate of $240 \mathrm{fps}$ for this class of cameras. The standard lens was replaced with a specialized one with improved characteristics, which are presented in Table 2 [23]. Its main advantage is high resolution, minimization of optical distortion and the ability to obtain the required focus distance in manual mode. 
Table 2 - Specifications of the lens.

\begin{tabular}{|l|l|}
\hline Focal length & $3,4 \mathrm{~mm}$ \\
\hline Aperture & $\mathrm{f} / 2,8$ \\
\hline Optical resolution & $20 \mathrm{MP}$ \\
\hline Horizontal shooting angle & $9^{\circ}$ \\
\hline Lens material & glass \\
\hline Optical distortion & without distortion $\leq 0,5 \%$ \\
\hline Number of elements & 8 \\
\hline Focusing & manual \\
\hline Minimum focus distance & o mm, focusing on the lens surface \\
\hline BFL & $3 \mathrm{~mm}$ \\
\hline Filter & IR \\
\hline
\end{tabular}

A special blade - plate - 3 was used for positioning in the flow direction, which also served as a screen for obtaining more contrasting images of particles (for this purpose, it was painted in a matte black color).

The technique for performing a full-scale experiment was as follows: initially, the system was configured, which included focusing in a given area (the size of the recorded area is $150 \times 100 \mathrm{~mm}$ ), setting the camera operation mode (chose of shooting parameters: the resolution and frame rate), turning on the backlight to work in continuous mode with maximum power . A calibration frame was also taken for the subsequent determination of the scale factor S (2). Then the meter was immersed in water at a given horizon using a telescopic rod. Three horizons were selected for work at each station: the surface, the midpoint of the station depth, and the bottom area. Thanks to the use of a special plate (Figure 1), which serves as a weather vane and a swivel located at the base of the rod, the installation was turned in the direction of the flow, allowing to make video shooting in its longitudinal section.

The physical principle of particles visualization in the developed meter is to register the light scattered by them. Special tracer particles are used in the classical PIV method, however, the application of this technology in the field is difficult and it requires a fairly long time to prepare and perform each measurement, as well as a large number of consumables. In accordance with this natural suspended particles already present in the stream were used as tracers, which made it possible to significantly simplify the technology of performing the experiment and reduce the cost of their implementation. As an example, Figure 2 shows a fragment of single frame from the video data obtained using the created meter during the expedition research at the mouth of the Chernaya river, 2019.

Registration was performed on the upper horizon in the near-surface area. The figure shows a special element that is located on the plate for additional calibration during subsequent analysis.

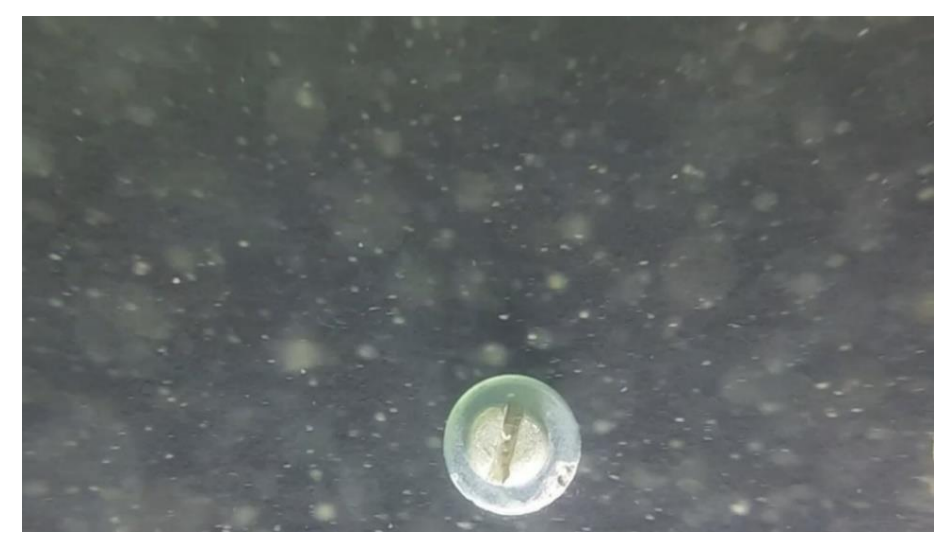

Figure 2 - An example of a frame of the received video image. 
The video data obtained with the help of the developed complex were subjected to software processing in several stages. At the first stage, preprocessing of the video file was performed, which included gamma correction, adjustment of contrast, image brightness, and performing binarization to obtain sharp images of suspended particles in focus.

Figure 3 shows the result of processing the video frame shown above.

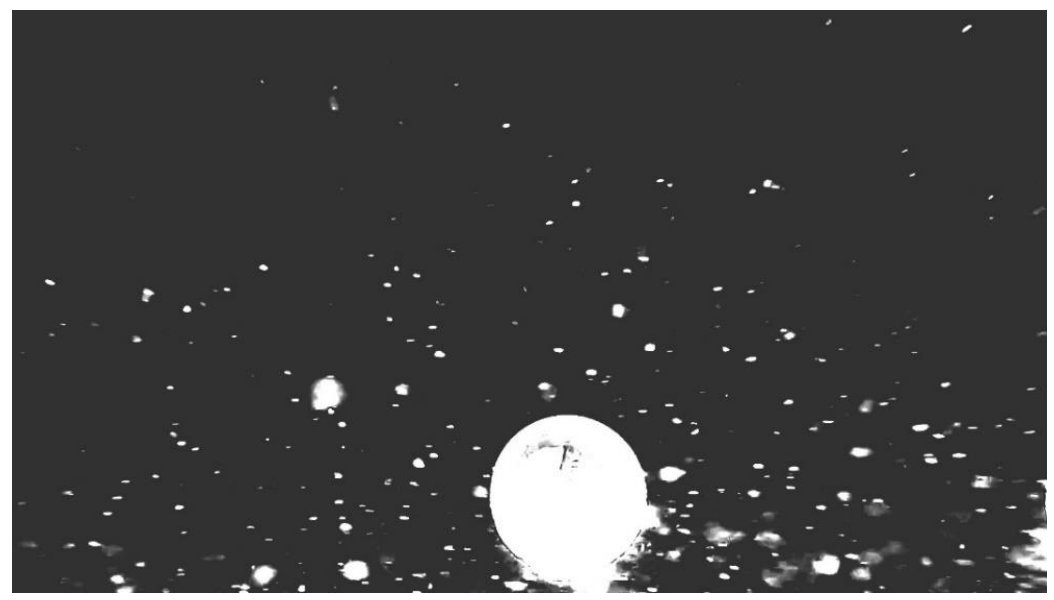

Figure 3 - The final frame after preprocessing.

Then the video file was split into successive frames using the application software. The time interval between frames was $4 \mathrm{MS}$ in accordance with the characteristics and settings of the equipment. As a result, an array of images in * jpg format was formed. The next step was the cross-correlation processing of pairs of sequential images, described above.

In order to increase the accuracy of measurements, an iterative procedure was used. Its essence was as follows: in the first iteration, relatively large fragments were used to calculate the offset more accurately (the larger the fragment, the better the signal-to-noise ratio and the more stable the cross-correlation).

However, large fragments give low vector resolution. Therefore, in the next iterations, a fragment was taken twice as small. The fragment displacement information in the first pass was used to calculate the displacement in the second iteration, and so on. This procedure provides high vector resolution and a good signal-to-noise ratio, resulting in accurate measurements.

Fragments of $256 \times 256$ pixels in the first iteration and $128 \times 128$ pixels in the second iteration were used for processing the images obtained in the course of the experiments. As a result, instantaneous flow velocity fields were constructed for each horizon. As an example, Figures 4-6 show images with the constructed instantaneous current velocity field for three horizons (surface, middle and bottom layers) of station No. 8, section No. 4, obtained in expeditionary studies at the mouth of the Chernaya river, Sevastopol in 2019. Research was carried out in the field of mixing sea and river water, which is characterized by an unstable flow structure. The highest velocity values were observed in the surface layer. In addition, the flow periodically changed direction to the opposite, which was recorded during measurements in the middle layer, Figure 5 . In addition, the current periodically changed direction to the opposite, which was recorded when performing measurements in the middle layer, Figure 5.The bottom layer is characterized by the presence of turbulent processes, which can be visualized and described using the developed meter (Figure 6).

The bottom layer is characterized by the presence of turbulent processes, which can be visualized and described thanks to the use of the developed meter (Figure 6). 


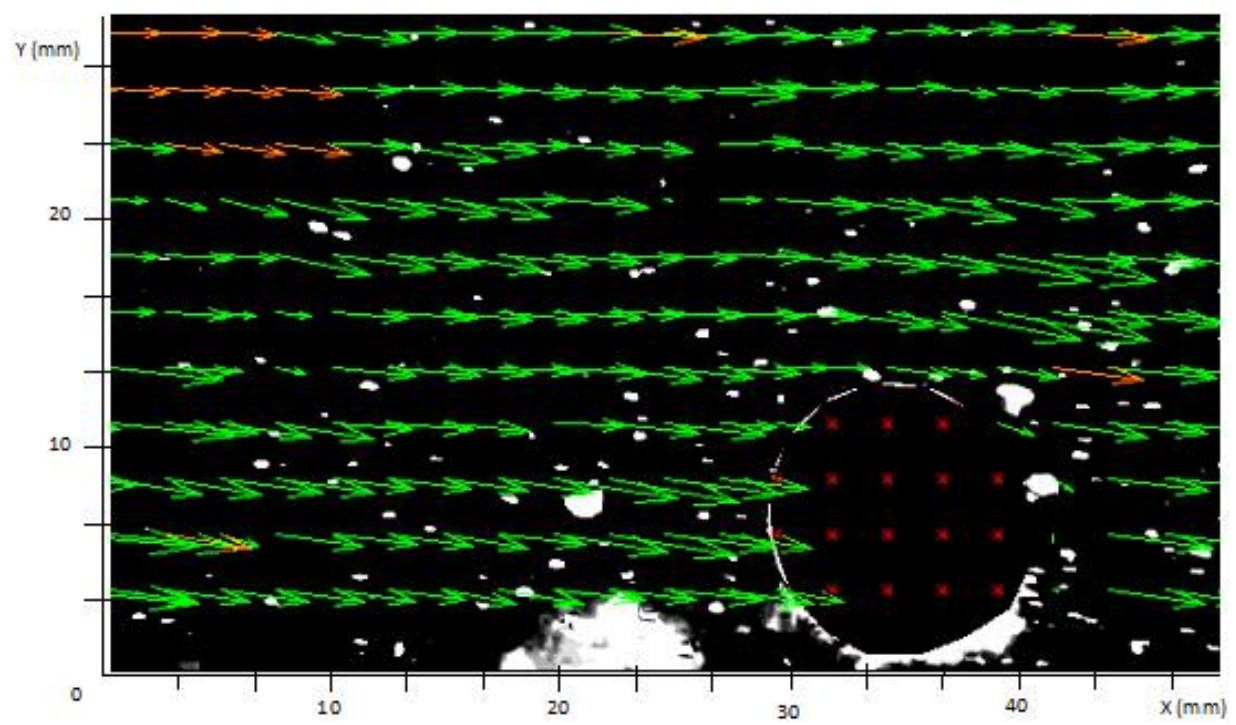

Figure 4 - Constructed instantaneous current velocity field in the surface layer.

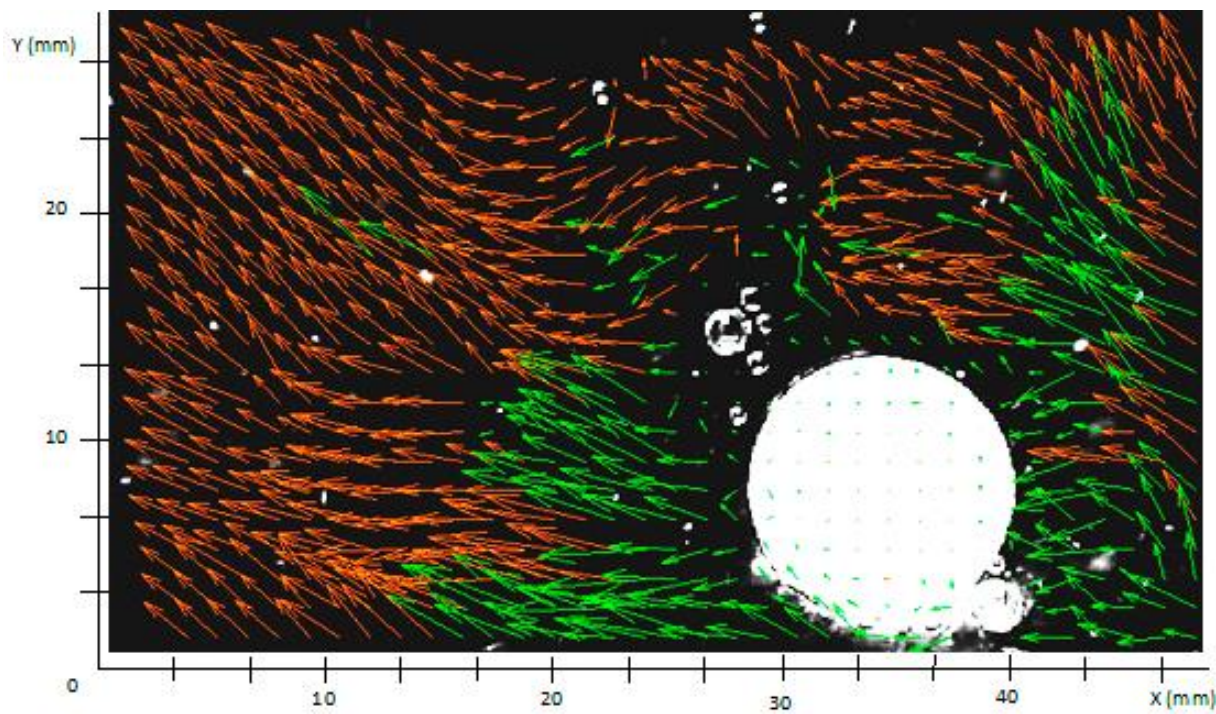

Figure 5 - Constructed instantaneous flow velocity field in the middle layer

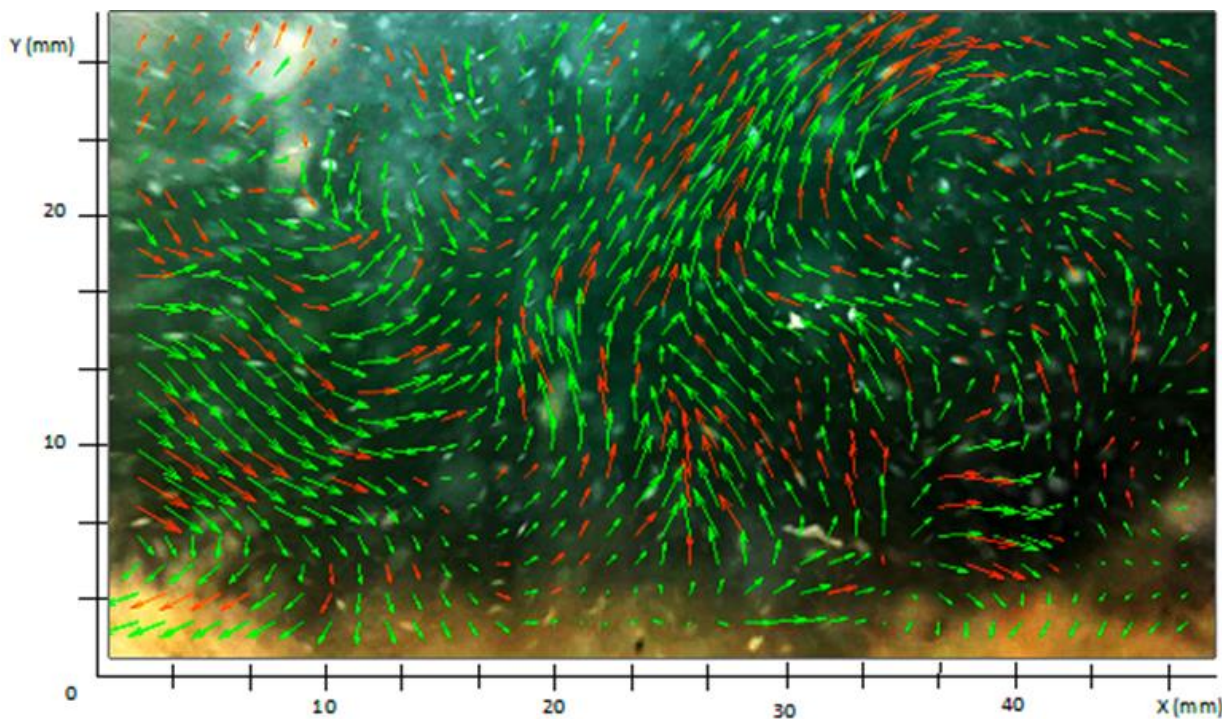

Figure 6 - Constructed instantaneous field of current velocity in the bottom layer. 
Statistical averaging of the obtained fields makes it possible to obtain the average value of the current velocity for each horizon, which is necessary for solving various problems of environmental monitoring.

Figure 7 shows a histogram of the distribution of the average flow velocity of the water flow for the bottom layer. According to the results of calculations, the average speed was 0.05 $\mathrm{m} / \mathrm{s}$.

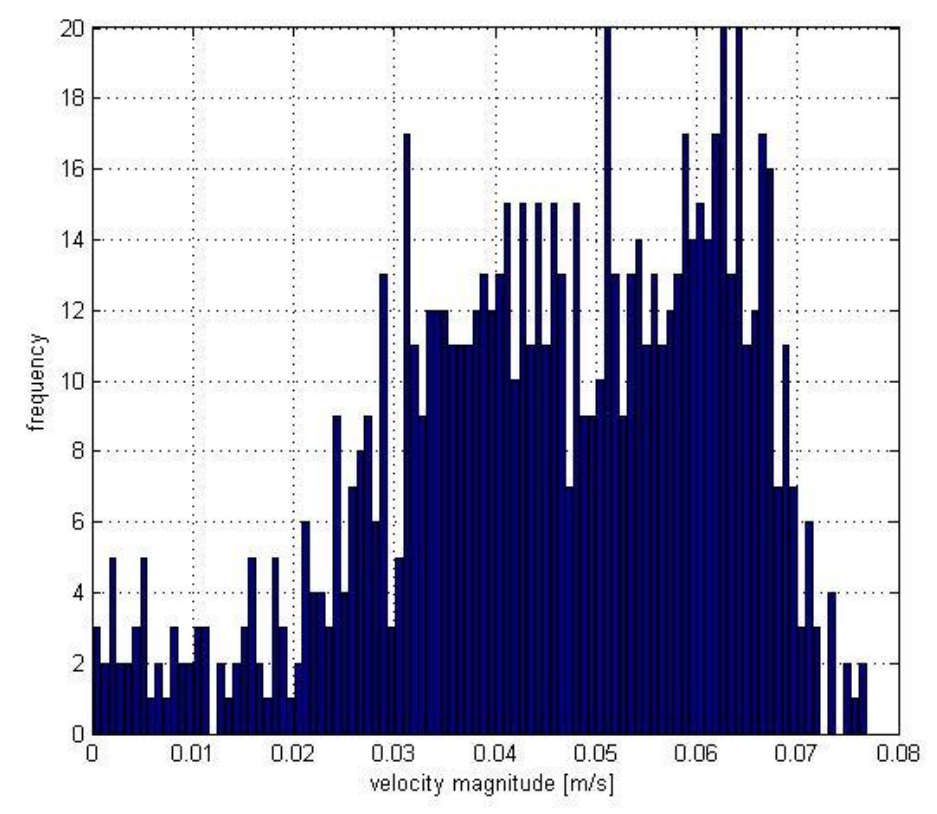

Figure 7 - Histogram of the distribution of the average water flow velocity.

To verify the data obtained, similar experiments were carried out in parallel to determine the flow rate using the Condor biophysical complex (NPP Aquastandard, TU 431230-00600241904-2015; EAEU code 902750 ooo o. Declaration of conformity of the EAEU N RU D-RU.EM03.A.00096 / 19) [24, 25], which includes a hydrometric spinner.

The research results using both methods are similar, the discrepancies do not exceed $9 \%$. This confirms the reliability and sufficiently high accuracy of the data obtained.

Thus, the developed meter allows performing field experiments to determine the flow velocity and obtain data on the dynamics of the water flow with velocity amplitudes up to 2 $\mathrm{m} / \mathrm{s}$. The use of standard components in its composition makes it easier to maintain and operate. The field tests carried out as part of the expedition research at the mouth of the Chernaya river, Sevastopol, showed good results.

Thanks to the use of modern visualization methods, the created meter has a number of advantages over other instruments for studying flows. In particular, it makes it possible to obtain instantaneous and averaged distribution fields of the current velocity in a wide spatial and temporal range, due to which it can be used to study complex turbulent flows, processes of bottom sediment transfer, which in turn makes it possible to obtain a more detailed understanding of the nature of the natural processes and their peculiarities.

The work was carried out within the framework of the state assignment on the topic No. o827-2019-0004 "Comprehensive interdisciplinary studies of Oceanological processes that determine the functioning and evolution of ecosystems in the coastal zones of the Black and the Azov Seas." 


\section{References}

1. Morozov A.N., Lemeshko E.M. Methodical aspects of the application of acoustic doppler current profilers in the Black sea // Physical Oceanography, 2006. №16 ( 4). P. 216233 .

2. Sabinin K.D., Serebryany A.N. The use of acoustic Doppler current profilometers for studying the spatial structure of the marine environment // Akusticheskiy zhurnal [Acoustic Journal], 2012, Vol. 58, No. 5. pp. 639-648. (in Russian)

3. Gartner J. Estimating suspended solids concentrations from backscatter intensity measured by acoustic Doppler current profiler in San Francisco Bay // California: Marine Geology. 2004, Vol. 211. P. 169-187.

4. Chang H.S. Ul'trazvukovoy sposob izmereniya skorosti techeniya [Ultrasonic method for measuring the flow velocity (options)]. Patent RF 2193208 C2, 11.20.2002. Application No. 99118673/28 of 08/25/1999. (in Russian)

5. Bendersky G.P., Vylegzhanin I.S., Vylegzhanina O.V., Korneev A.N., Ponomarenko A.I., Pushkov A.A. Ul'trazvukovoy sposob izmereniya skorosti techeniya i raskhoda vody $\mathrm{v}$ otkrytykh vodoyemakh. [Ultrasonic method for measuring the flow velocity and water flow in open waters]. Patent RF 2664456 C2, 08.20.2018. Application No. 2016145752 dated 11/22/2016. (in Russian)

6. Dykman V.Z., Efremov O.I., Barabash V.A. Ustroystvo dlya izmereniya pul'satsiy skorosti potoka elektroprovodnoy zhidkosti. [A device for measuring the pulsations of the conductive fluid flow velocity]. Patent RF 2548126 C1, 04/10/2015. Application No. 2014151935/93 dated 12/18/2014. (in Russian)

7. Dykman V.Z. Technical tools for studying structure and dynamics of water masses// Physical oceanography. 2016, № 6 (192). P. 43-55.

8. Klimenko D.E. Razvitiye gidrometricheskikh vertushek v Rossii i za rubezhom [The development of hydrometric turntables in Russia and abroad] // Geograficheskiy vestnik [Geographical Bulletin]. 2010, No. 2 (13).pp. 64-76. (in Russian)

9. Bykov V.D. Gidrometriya [Hydrometry] / V.D. Bykov, A.V. Vasiliev // L.: Gidrometeoizdat, 1977, 448 p. (in Russian)

10. Mosharov V.E., Radchenko V.N. Novyy metod vizualizatsii techeniy na poverkhnosti aerodinamicheskikh modeley [A new method for visualizing flows on the surface of aerodynamic models] // Datchiki i sistemy [Sensors and Systems]. 2010, No. 5. pp. 48-53. (in Russian)

11. Skornyakova N.M., Sychev D.G., Varaksin A.Yu., Romash M.E. Vizualizatsiya vikhrevykh struktur metodom anemometrii po izobrazheniyam chastits [Visualization of vortex structures by anemometry using particle images] // Nauchnaya vizualizatsiya [Scientific Visualization]. 2015, Vol. 7. No. 3. pp. 15-24. (in Russian)

12. Gobyzov OA, Lozhkin Yu.A., Ganiev Yu.Kh., Zakharov EP, Filippov S.E. Issledovaniye polya potoka $\mathrm{v}$ rabochey chasti sverkhzvukovoy aerodinamicheskoy truby metodom anemometrii po izobrazheniyam chastits [Investigation of the flow field in the working part of a supersonic wind tunnel by anemometry using particle images] // Kosmonavtika i raketostroyeniye [Cosmonautics and rocket science]. 2014, No. 4 (77). pp. 26-33. (in Russian)

13. Evtikhieva O.A., Shashkova I.A., Skornyakova N.M. Vizualizatsiya plenochnogo techeniya zhidkosti metodom anemometrii po izobrazheniyam chastits [Visualization of the film fluid flow by anemometry using particle images] // Bulletin of the Moscow Power Engineering Institute. Vestnik Moskovskogo energeticheskogo instituta [Bulletin of MPEI]. 2015, No. 3. pp. 71-73. (in Russian) 
14. Biswas S. Schlieren Image Velocimetry (SIV). In: Physics of Turbulent Jet Ignition. Springer Theses (Recognizing Outstanding Ph.D. Research). Springer, Cham. 2018. https://doi.org/10.1007/978-3-319-76243-2_3

15. Hargather, M.J., et al.: Seedless velocimetry measurements by Schlieren Image Velocimetry. AIAA J. 2011, 49(3), P. 611-620.

16. Znamenskaya I.A., Koroteeva E.Yu., Glazyrin F.N. Metody tsifrovogo analiza izobrazheniy zhidkikh i gazoplazmennykh potokov na osnove krosskorrelyatsionnoy obrabotki [Methods for digital analysis of images of liquid and gas-plasma flows based on crosscorrelation processing] // Nauchnaya vizualizatsiya [Scientific visualization]. 2018, Vol. 10, No. 4. P. 100-108. (in Russian)

17. Jahanmiri M. Particle Image Velocimetry: Fundamentals and Its Applications. Research report 2011:03. Department of applied mechanics, Chalmers university of technology, Göteborg, Sweden. 2011. 58 p.

18. Khmelevoy S.V. Ispol'zovaniye GPU dlya raschetov skorostey gazo-zhidkostnykh sred s pomoshch'yu metoda PIV [Using GPU for calculating the velocities of gas-liquid media using the PIV method] // Radioelektronnyye i komp'yuternyye sistemy [Radioelectronic and computer systems]. 2012, № 6 (58). pp. 124-129. (in Russian)

19. Sergeyev D.A. Izmeritel'nyy kompleks dlya issledovaniya techeniy zhidkosti metodom probny chastits na osnove tverdotel'nogo lazera $s$ diodnoy nakachkoy [A measuring complex for studying fluid flows by the particle probe method based on a diode-pumped solid-state laser] // Pribory i tekhnika eksperimenta [Instruments and experimental technique]. 2009, №3. pp. 138-144. (in Russian)

20. Akhmetbekov E.K., Bilskiy A.V., Lozhkin Yu.A., Markovich D.M., Tokarev M.P., Tyuryushkin A.N. Sistema upravleniya eksperimentom i obrabotki dannykh, poluchennykh metodami tsifrovoy trassernoy vizualizatsii [Experiment control system and data processing obtained by digital tracer visualization methods (ActualFlow)] // Vychislitel'nyye metody i programmirovaniye [Computational methods and programming]. 2006, No. 7. pp. 79-85. (in Russian)

21. Sergeyev D.A. Ispol'zovaniye sovremennykh metodov anemometrii po izobrazheniyam chastits (PIV-metodov) pri laboratornom modelirovanii geofizicheskikh techeniy [The use of modern methods of anemometry from particle images (PIV methods) in laboratory modeling of geophysical currents] // Vestnik Nizhegorodskogo universiteta im. N.I. Lobachevskogo [Bulletin of Nizhny Novgorod University. N.I. Lobachevsky]. 2011, No. 4 (2). pp. 522-524. (in Russian)

22. The YI4k+ camera technical specifications Available at: http://yitechnology.ru/actioncamera/specs/id/11 (accessed 09.06.2020). (in Russian)

23. The $3.4 \mathrm{~mm}$ DUO lens with focus adjustment for Yi4K / $4 \mathrm{~K}+$. Available at: https://www.pixaero.pro/catalog/pixaerolens/dlya_yi/obektiv_3_4mm_duo_s_regulir ovkoy_rezkosti_dlya_ekshn_kamer_yi (accessed 09.06.2020).

24. Chepyzhenko A. A., Chepyzhenko A. I. Methods and device for in situ total suspended matter (TSM) monitoring in natural waters' environment, Proc. SPIE 10466, 23rd International Symposium on Atmospheric and Ocean Optics: Atmospheric Physics, 104663G (30 November 2017); DOI: 10.1117/12.2287127

25. Chepyzhenko A. I., Chepyzhenko A. A. Methods and device for in situ dissolved organic matter (DOM) monitoring in natural waters' environment, Proc. SPIE 10466, 23rd International Symposium on Atmospheric and Ocean Optics: Atmospheric Physics, 104663S (30 November 2017); DOI: 10.1117/12.2287797 